\title{
A Study on Water Quality Parameters of Water Supply in Sylhet City Corporation Area
}

\author{
Gulam Md. Munna, Shriful Islam, N. M. R. Hoque, K. Bhattacharya, S. D. Nath \\ Dept. of Civil and Environmental Engineering, Shahjalal University of Science and Technology, Sylhet, Bangladesh
}

Email address:

munna192@yahoo.com (G. Md. Munna), sharif_sust_cee@yahoo.com (S. Islam), snmr.hoque@gmail.com (N. M. R. Hoque), kowshik.cee@gmail.com (K. Bhattacharya),shuvrodebnath@yahoo.com (S. D. Nath)

\section{To cite this article:}

G. Md. Munna, Shriful Islam, N. M. R. Hoque, K. Bhattacharya, S. D. Nath. A Study on Water Quality Parameters of Water Supply in Sylhet City Corporation Area. Hydrology. Vol. 3, No. 6, 2015, pp. 66-71. doi: 10.11648/j.hyd.20150306.12

\begin{abstract}
An investigation was carried out to assess the water quality parameters of water supplied by Sylhet City Corporation (SCC).The supplied water quality is at risk to deteriorate during its flow through the delivery system and/or due to the possibility of high elemental concentration in ground water. In SCC, there are 23 pumps available that continually supply water for city dwellers. The parameter analyzed are like $\mathrm{pH}$, turbidity, hardness, chloride, TDS (Total dissolved solid), arsenic, iron, FC (Fecal Coliform) and TC (Total Coliform). All results are compared with the World Health Organization (WHO), Bangladesh Standard (BD) and the Indian Standard Institute (ISI).The investigation discovers that the value of turbidity and iron in the location of Christian Mission designated by S-11 crosses the all three standard. The measurement of TDS and chloride shows that the values are within the safe limit. Analysis of arsenic and FC water quality parameter revealed that there are no arsenic and fecal coliform contamination. The water treatment facilities of SCC have to be enhanced; necessary steps should be taken to reduce the contamination and adequate treatment facility should be promoted.
\end{abstract}

Keywords: Water Quality Parameter, Water Supply, pH, Iron, Turbidity

\section{Introduction}

The important consideration and the main responsibility of the modern public health engineering is to supply potable water to the general people. Potable water is one which is safe to drink pleasant to taste and suitable for domestic uses. About $80 \%$ of all diseases and two third of deaths in developing countries are attributed to consumption of low quality water, and on an average $10 \%$ of ones' productive time is sacrificed to such diseases[1]. Water is involved in the spread of communicable diseases in essentially two ways. The well-known direct ingestion of infectious agent is the contaminated drinking water. The second is due to a lack of sufficient water for personal hygiene purposes. The quality of drinking water is at high risk in Bangladesh. Problems are severe, particularly in the urban areas due to high migration rate of rural people and increased economic growth as well $[1,2]$.

Most of the city dwellers in Sylhet depend on the SCC water supply even though some people fulfill their requirements by themselves. As most of the city dwellers rely on this water supply, the quality of water distributed by SCC in vital for the health of the city dwellers. There are mainly three types of constituents or parameters for describing the quality of water, i.e. physiological, chemical and biological parameters. Observation about water quality, based on visual examination such as, color, taste, and odor is often unpredictable.

In Sylhet City Corporation, 23 pump station and Surface Water Treatment Plant (SWTP) supply water to city dwellers for drinking and household-usage purpose. In this study different water quality parameters like $\mathrm{pH}$, total hardness $(\mathrm{TH})$, total dissolved solids (TDS), chloride, iron, arsenic, total coliform, fecal coliform are tested from samples collected near the sources of the pump station and the results are compared with the WHO, BD and ISI standards. The result of this study will be beneficial for the planners and decision makers to device policy guideline for efficient management of water supply source.

\section{Study Area, Materials and Methodology}

Sylhet City is situated by the side of the Surma River- at the northeast region of the country and situated at $28.85^{\circ}$ latitude 
and $98.80^{\circ}$ longitude [3].SylhetPourashava established in the year 2002 covering an area of 26.5 sq. $\mathrm{km}$ [3] and sub-divided year 1878 and promoted to the City Corporation during the into 27 \# of Wards (Fig. 1).

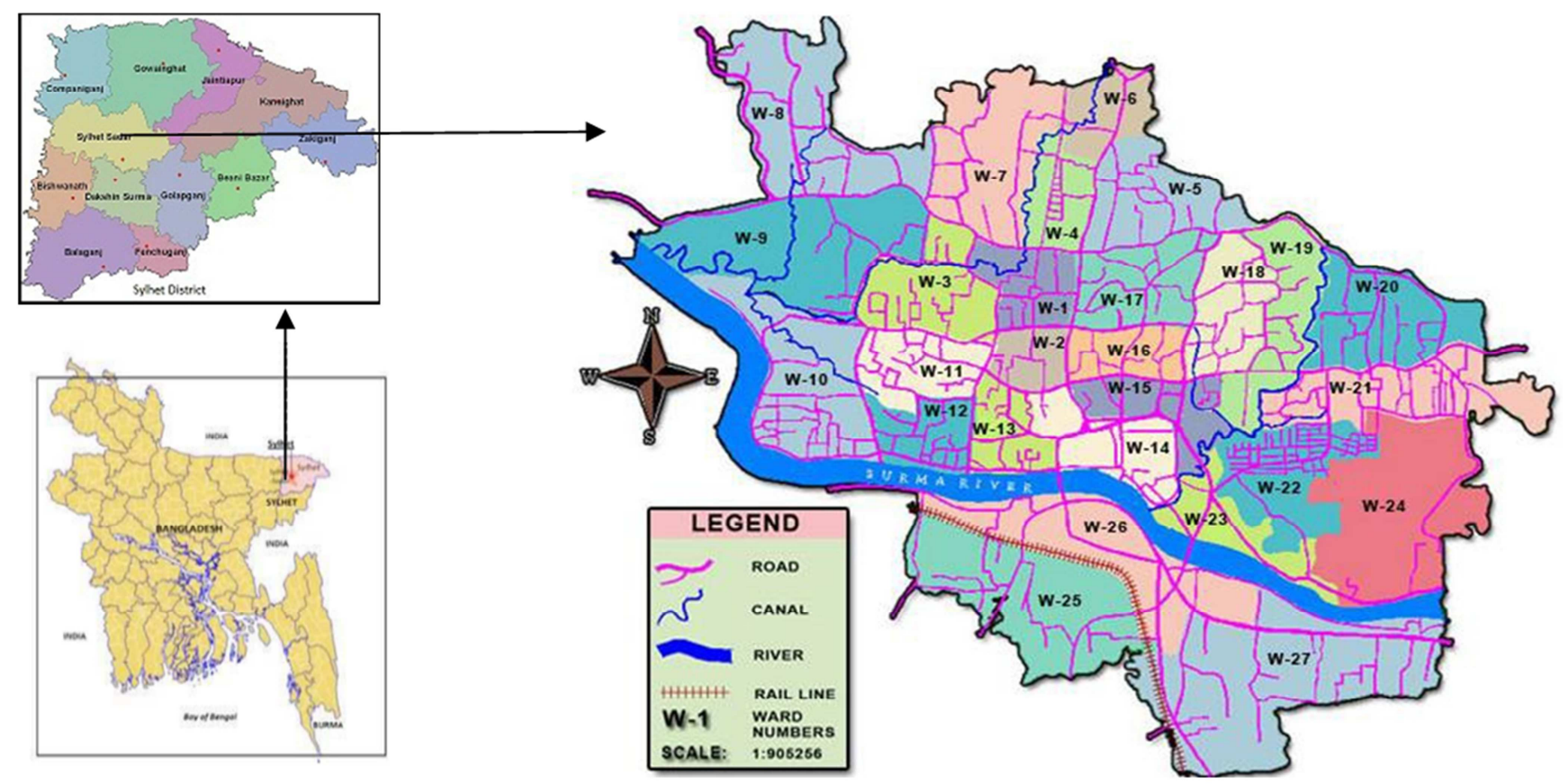

Figure 1. Study area and location of sampling points [9].

Table 1. Comparison of water quality parameter with WHO [5], BD[6] and ISI[7] standards.

\begin{tabular}{|c|c|c|c|c|c|c|c|c|c|c|}
\hline S No. & $\begin{array}{l}\text { Name of the source Pumping } \\
\text { Stations }\end{array}$ & pH & $\begin{array}{l}\text { Turbidity } \\
\text { (NTU) }\end{array}$ & $\begin{array}{l}\text { TDS } \\
(\mathrm{mg} / \mathrm{L})\end{array}$ & $\begin{array}{l}\text { Hardness } \\
(\mathrm{mg} / \mathrm{L})\end{array}$ & $\begin{array}{l}\text { Chloride } \\
(\mathrm{mg} / \mathrm{L})\end{array}$ & $\begin{array}{l}\text { IRON } \\
(\mathrm{mg} / \mathrm{L})\end{array}$ & $\begin{array}{l}\text { ARSENIC } \\
(\mathrm{mg} / \mathrm{L})\end{array}$ & $\begin{array}{l}\text { FC } \\
(\mathrm{N} / \mathbf{1 0 0 g})\end{array}$ & $\begin{array}{l}\text { TC } \\
(\mathrm{N} / \mathbf{1 0 0 g})\end{array}$ \\
\hline S-1 & Old Medical Colony & 6.30 & 3.42 & 281 & 50.00 & 8.50 & 0.44 & 0 & 0 & 0 \\
\hline S-2 & Bornomala School & 6.01 & 0.57 & 241 & 69.40 & 13.80 & 0.43 & 0 & 0 & 0 \\
\hline S-3 & Dept. of public Health & 6.60 & 1.02 & 172 & 64.60 & 6.60 & 0.61 & 0 & 0 & 0 \\
\hline S-4 & Rikabibazar & 6.76 & 5.20 & 292 & 39.30 & 12.00 & 0.33 & 0 & 0 & 0 \\
\hline S-5 & Osmani Medical & 6.76 & 1.10 & 316 & 74.00 & 11.33 & 0.51 & 0 & 0 & 1 \\
\hline S-7 & Korer Para & 6.50 & 1.52 & 235 & 62.00 & 3.90 & 0.59 & 0 & 0 & 0 \\
\hline S-8 & MotshoVobon opposite & 6.80 & 0.00 & 365 & 266.00 & 4.30 & 0.57 & 0 & 0 & 0 \\
\hline S-9 & PTI & 7.18 & 0.00 & 209 & 284.00 & 17.00 & 0.40 & 0 & 0 & 0 \\
\hline S-10 & Kazitula & 6.95 & 0.00 & 280 & 41.00 & 10.00 & 0.47 & 0 & 0 & 0 \\
\hline S-11 & Christian Mission & 7.17 & 4.65 & 208 & 43.30 & 15.67 & 1.30 & 0 & 0 & 2 \\
\hline S-12 & Mazar side & 7.43 & 0.00 & 171 & 32.67 & 10.00 & 0.54 & 0 & 0 & 0 \\
\hline S-13 & ShahiEidgahUchasorok & 6.93 & 0.32 & 274 & 37.00 & 12.67 & 0.28 & 0 & 0 & 0 \\
\hline S-15 & TT gate point & 6.90 & 1.46 & 237 & 60.67 & 10.00 & 0.37 & 0 & 0 & 1 \\
\hline S-16 & Baluchor point Pump 1 & 6.90 & 0.82 & 180 & 44.00 & 8.67 & 0.39 & 0 & 0 & 2 \\
\hline S-17 & Baluchor point pump 2 & 7.10 & 1.65 & 235 & 74.67 & 6.60 & 0.45 & 0 & 0 & 0 \\
\hline S-18 & Choukidekhi & 6.60 & 1.97 & 213 & 96.30 & 12.33 & 0.42 & 0 & 0 & 1 \\
\hline S-19 & Near Biman Office & 7.13 & 1.20 & 226 & 60.30 & 12.67 & 0.65 & 0 & 0 & 1 \\
\hline S-20 & Pathantula & 6.60 & 0.76 & 199 & 66.00 & 7.00 & 0.35 & 0 & 0 & 0 \\
\hline S-21 & DorshonDeuri & 6.20 & 0.49 & 227 & 47.00 & 11.00 & 0.61 & 0 & 0 & 1 \\
\hline S-22 & Police Line Pump & 6.34 & 1.22 & 197 & 88.30 & 4.73 & 0.54 & 0 & 0 & 0 \\
\hline S-23 & Goai Para pump & 6.24 & 1.40 & 244 & 30.00 & 8.00 & 0.48 & 0 & 0 & 0 \\
\hline \multirow{3}{*}{ Standards } & WHO & $6.5-8.4$ & 5 & 1000 & 500 & 250 & 0.3 & 0.01 & 0 & 0 \\
\hline & $\mathrm{BD}$ & $6.5-8.5$ & 10 & 1000 & $200-500$ & $150-600$ & $0.3-1$ & 0.05 & 0 & 0 \\
\hline & ISI & $6.5-8.6$ & 5 & 500 & 300 & 250 & 0.3 & 0.05 & 0 & 0 \\
\hline
\end{tabular}

Groundwater with Deep Tube Well (DTW) is the main source of the present water supply system in Sylhet City Corporation and there is an existing Surface Water Treatment
Plant (SWTP) at Sylhet constructed in 1918, which is producing about $600 \mathrm{~m}^{3} /$ day, i.e., 0.6 MLD (1\% of surface water and 99\% from ground water). Moreover, in the southern part of the city, 
there is no suitable groundwater aquifer within the city and as such in order to improve the situation conjunctive use of surface and groundwater has been recommended by decreasing groundwater abstraction gradually.

There are 23 pump stations in the SCC area; 3 water samples from household near the every station, so total 69 samples are collected in 2 liter capacity airtight sterile containers. The household connections are chosen as far as possible from the main station so that any significant pollution from pipe leakage or other purpose can easily be identified. Physical and chemical parameters like $\mathrm{pH}$, turbidity, total dissolved solids (TDS), hardness, chloride, iron, arsenic, fecal chloroform (FC), and total chloroform (TC) have been tested in the collected sample water.

The $\mathrm{pH}$ and turbidity were measured by digital $\mathrm{pH}$ meter (HANNA, HI 8014) and digital turbidity meter (HANNA), respectively. Total dissolved solids (TDS) was determine according to standard method of ASTM D 5907 [4].

Total hardness $(\mathrm{TH})$ was determined by the Soda Reagent method. Chloride was determined in Mohr's method by titration with a standard silver nitrate solution in the presence of potassium chromate indicator. Iron was determined by the production of red colored iron compound (ferric thiocyanate), by the addition of potassium thiocyanate. The Ultraviolet Spectrophotometer was used for detection of the amount of color change. Arsenic concentration in the water sample was determined by silver diethyldithiocarbamate (SDDC). Membrane filter technique and biological kit box was used for determining fecal chloroform (FC) and total chloroform (TC), respectively.

\section{Results and Discussion}

In this investigation, the current condition of the quality of water distributed by SCC is determined by measuring the physico-chemical and microbial properties. $\mathrm{pH}$, turbidity, total dissolved solids (TDS), hardness, chloride, iron, arsenic, fecal chloroform (FC) and total chloroform (TC) are determined in the laboratory through water sample test and results are compared with WHO [5], BD [6] and ISI[7] standard value in Table 1.

\section{1. $\mathrm{pH}$}

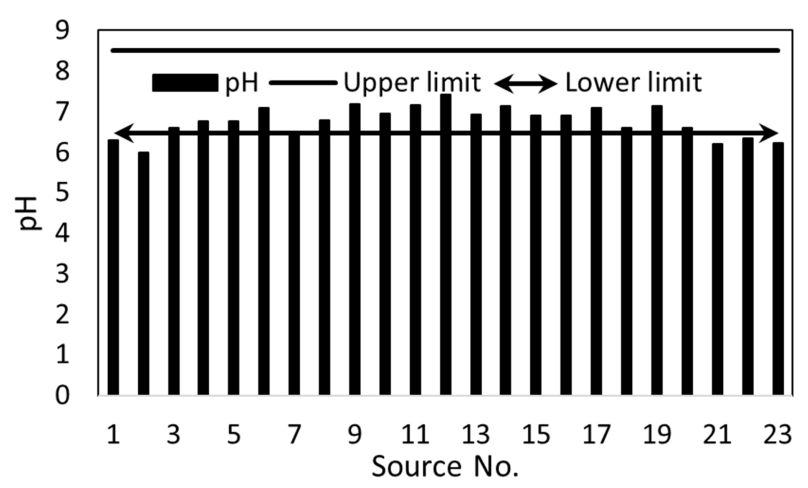

Figure 2. $p H$ value of different water samples.

The $\mathrm{pH}$ of all sources varies between 6.01 and 7.43 (Fig. 2).
All three standard (WHO [5], BD [6] and IS [7]) recommended that the $\mathrm{pH}$ values should be in the range of 6.5 to 8.5. Out of 23 sources; the water sample of 18 sources are within the standard range and that of remaining 5 sources are below the guideline value varying between 6.01 and 6.34. At lower $\mathrm{pH}$ water is likely to be corrosive due to acidity [1]. So lower $\mathrm{pH}$ water from those sources must be controlled to minimize the corrosion of the distribution system. Failure or leakage of delivery system due to corrosion may contaminate the water or affect adversely on its odor, taste and appearance. In 2010, Hoque et al. [1] investigate the water quality of 20 samples from different ward and found 7 samples that below the acceptable limit. An investigation revealed that the ground water provides lower $\mathrm{pH}$ value within the dumping zone [8].

\subsection{Turbidity}

The study shows that the turbidity of all sources is found in the range between 0 to 12.45 NTU (Fig. 3). According to WHO [5] and ISI [7] (acceptable values $\leq 5$ NTU), source no. 4 (Rikabibazar) and 11 (Christian Mission) are found to be unacceptable for drinking purposes. However, according to BD [6] (acceptable values $\leq 10$ NTU), 1 source (Christian Mission which is denoted by source no. 11)is found to be affected with excess turbidity.

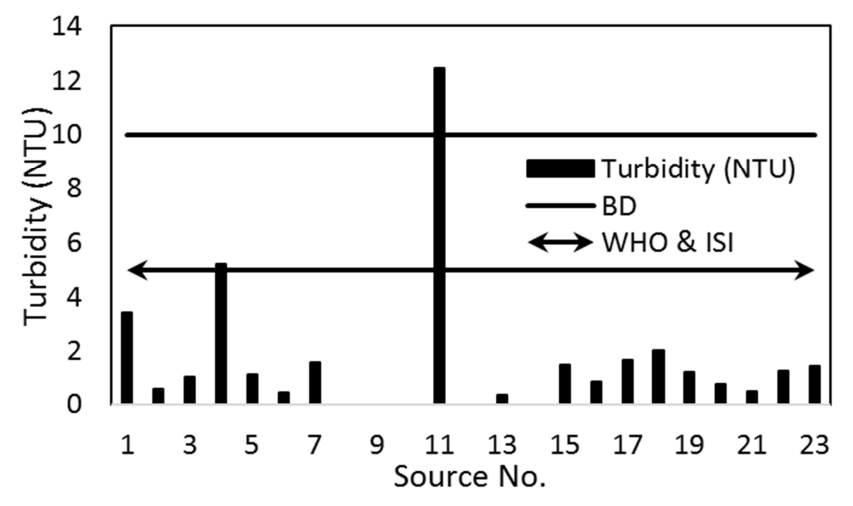

Figure 3. Turbidity in water samples (NTU).

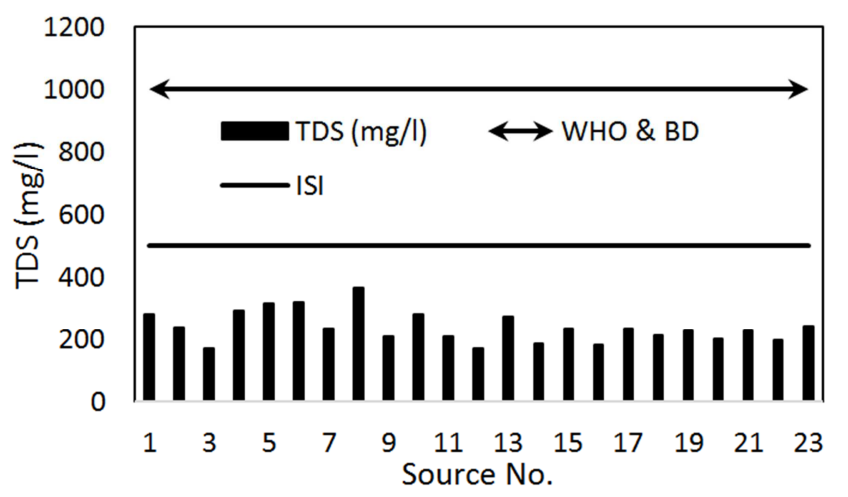

Figure 4. TDS value of different water samples $(\mathrm{mg} / \mathrm{L})$.

\subsection{Total Dissolved Solids (TDS)}

For WHO [5] and BD [6], the acceptable limit is $1000 \mathrm{mg} / \mathrm{L}$ and for the ISI [7], it is $500 \mathrm{mg} / \mathrm{L}$. The total dissolved solids (TDS) of all sources vary between $171 \mathrm{mg} / \mathrm{Land} 365 \mathrm{mg} / \mathrm{L}$ (Fig. 
4). So the values of TDS concentration in the water of all sources follow the standard limit.

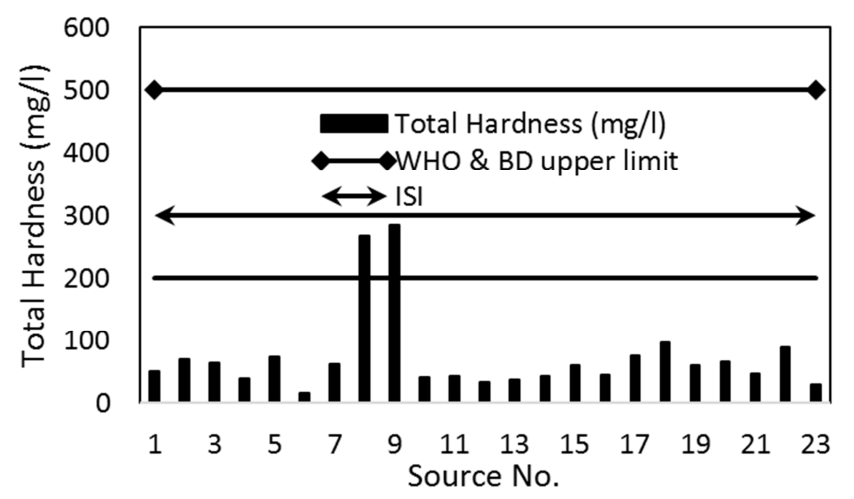

Figure 5. Total Hardness in water samples $(\mathrm{mg} / \mathrm{L})$.

\subsection{Total Hardness (TH)}

The total hardness is defined as the sum of the calcium and magnesium concentrations. The main problem of hardness is that the hard water consumes too much soap. All sources provide total hardness $(\mathrm{TH})$ ranging from $16.67 \mathrm{mg} / \mathrm{L}$ to 284 $\mathrm{mg} / \mathrm{L}$ (Fig. 5). So they are soft to very hard water and all values are in acceptable limit (WHO [5] $500 \mathrm{mg} / \mathrm{L}$, Bangladesh Standard [6] 200-500 $\mathrm{mg} / \mathrm{L}$ and ISI [7] $300 \mathrm{mg} / \mathrm{L}$ ).Hoque et al. [1] found that all sample values are lying in the range of $56-150 \mathrm{mg} / \mathrm{L}$. An investigation exposed that total hardness in Sylhet City groundwater are: within dumping place is $4564 \mathrm{mg} / \mathrm{L}$, near dumping place is 610 $\mathrm{mg} /$ Land remote from dumping place is $204 \mathrm{mg} / \mathrm{L}[8]$.

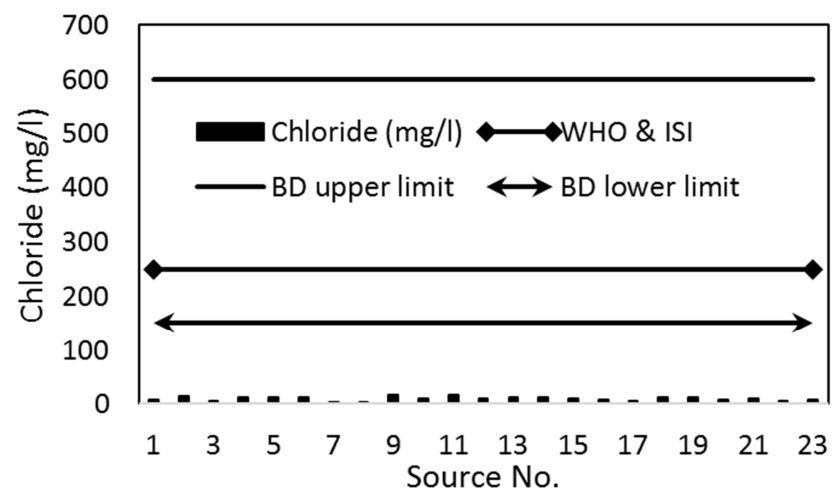

Figure 6. Chloride in water samples ( $\mathrm{mg} / \mathrm{L})$.

\subsection{Chloride}

Naturally chlorides rise in water in changeable concentrations. No proof has been established to specify that consumption of chloride is dangerous to human though high chloride content may damage metallic pipes and structures as well as growing plants [1]. The chloride concentrations range between $3.9 \mathrm{mg} / \mathrm{L}$ and $17 \mathrm{mg} / \mathrm{L}$ (Fig. 6) which is safe for human according to all standards. The investigation of Hoque et al. [1] found the similar result. But Alam et al. [8] found that chloride concentrations $(\mathrm{mg} / \mathrm{L})$ in Sylhet City increased up to $3458 \mathrm{mg} / \mathrm{L}$ in groundwater within the dumping zone.

\subsection{Iron}

Several milligrams per liter of ferrous iron concentration may contain in the anaerobic ground water. The ferrous iron oxidizes to ferric iron when it exposes to the atmosphere and turns into disagreeable reddish brown water. The excessive amount of iron concentration causes pipe clogging, growth of iron bacteria, reddish water color, undesirable taste in beverages, staining of clothes, etc. [1]. According to this study, the iron of all sources fluctuated from $0.12 \mathrm{mg} / \mathrm{L}$ to $1.3 \mathrm{mg} / \mathrm{L}$. Fig. 7 shows that 21 sources out of 23 crosses the acceptable limit according to WHO[5] and ISI [7]. In contrast, all sources except sources no. $11(1.3 \mathrm{mg} / \mathrm{L})$ are not within the range of 0.3 $\mathrm{mg} / \mathrm{L}$ to $1 \mathrm{mg} / \mathrm{L}$ according to Bangladesh Standard. Hoque et al. [1] found 3 sources of water sample $(0.31 \mathrm{mg} / \mathrm{L}, 0.53 \mathrm{mg} / \mathrm{L}$ and $3.65 \mathrm{mg} / \mathrm{L}$ ) out of 20 in the study area cross the standard limit of WHO [5] and ISI [7].Alam et al. [8] found that iron concentrations $(\mathrm{mg} / \mathrm{L})$ in Sylhet City groundwater are within dumping place is 133.5, near dumping place is 1.48 and remote from dumping place is 0.21 .

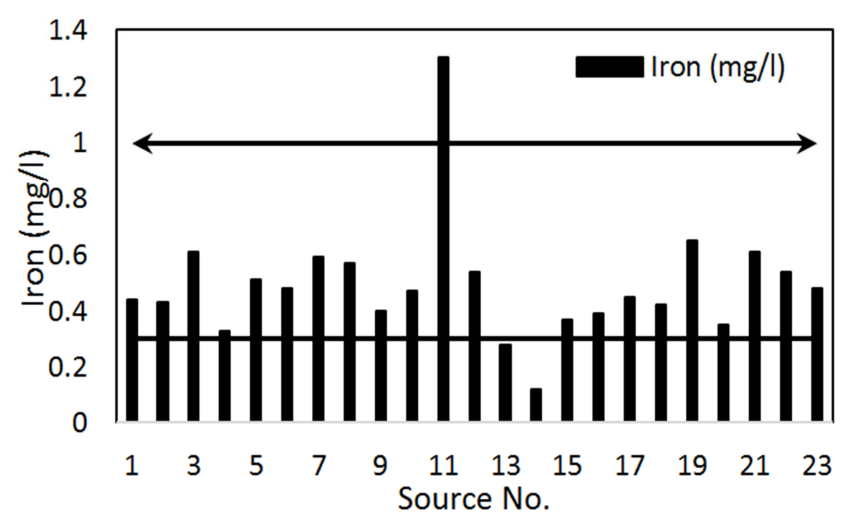

Figure 7. Iron in water samples $(\mathrm{mg} / \mathrm{L})$.

\subsection{Arsenic}

Arsenicosis is a recognized and extensive crisis in Bangladesh. It possesses the greatest threat of cancer. However, all the samples collected from different sources from SCC are free from arsenic.

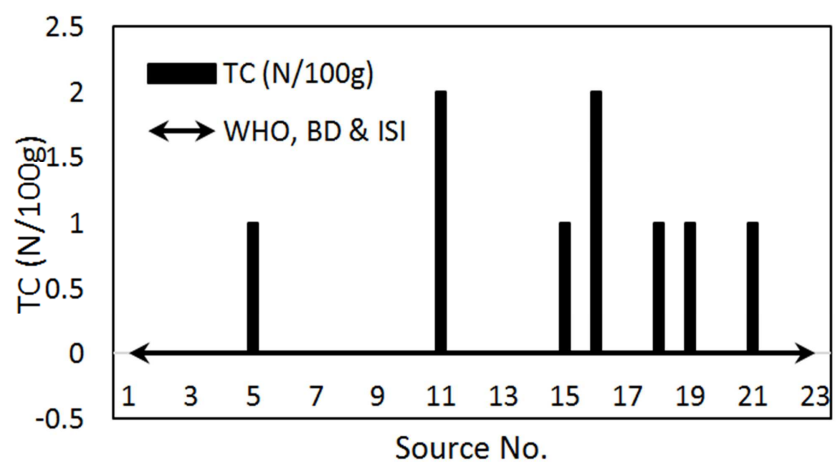

Figure 8. Total Coliform in water samples $(\mathrm{N} / 100 \mathrm{ml})$.

\subsection{Fecal Coliform (FC) and Total Coliform (TC)}

Fecal coliform is the group of the total coliforms that are 
considered to be present specifically in the gut and feces of warm-blooded animals. Fecal coliform is responsible for micro-organic borne diseases in the human body which is often discovered in human feces. The fecal coliform differs from other coliforms in that the fecal coliform can raise at $45^{\circ} \mathrm{C}$, i.e., they are thermo tolerant [1]. No fecal coliform found in any sources of water sample in the study area. But Alam et al. [8] found that in Sylhet City, the drinking water of each restaurant is contaminated with fecal coliforms.

Total coliforms include bacteria that are found in soil and water that has been influenced by surface water, and with human or animal waste. The presence of total coliforms vary from 0 to $2 \mathrm{~N} / 100 \mathrm{ml}$ of TC (Fig. 8). 7 sources out of 23 are affected with $\mathrm{TC}$ according to the three standards used in comparison in this study. Among 7 sources, sources no. 11 (Christian Mission) and 16 (Baluchor point Pump 1) provide 2 $\mathrm{N} / 100 \mathrm{ml}$ of TC.

\section{Conclusion}

The study was done to monitor the existing water quality supplied by the Sylhet City Corporation and to find out significant pollution in supply water from the source. The result of this study will be helpful to provide safe, drinkable water to the people living in Sylhet City Corporation area. As an emerging mega city the water supply authority of Sylhet must be concerned about water quality as like quantity. After analyzing the present situation, the study has come to its conclusion remarks as followings:

1. The Sylhet City Corporation has very little or no regular monitoring activity to check the quality of water it provides to the consumer. Most of the water pump stations provide acceptable drinking water, which is excellent for drinking and household uses considering the turbidity, total dissolved solids, chloride, arsenic and fecal coliform.

2. There are 5 sources of water having low water $\mathrm{pH}$, but none of this is life-threatening. All sources are free from hardness except source no. 8 (MotshoVobon opposite) and 9 (PTI), though they are in acceptable range according to WHO[5] and ISI [7].Only 2 sources (ShahiEidgahUchasorok and HazaribaghAbasik) are totally safe for drinking purpose considering iron contamination, according to $\mathrm{WHO}[5]$, Bangladesh standard[6] and Indian standard[7].

3. Most of the sources require treatment facility to reduce the iron concentration level. Source no. 11 (Christian Mission) requires treatment for turbidity, iron and total coliform to ensure the safe drinking water. Source no. 5 (Osmani Medical), 15 (TT gate point), 16 (Baluchor point Pump 1), 18 (Choukidekhi), 19 (Near Biman Office) and 21 (DorshonDeuri) required treatment to remove total coliform.

In 2009, Zuthi et al. [2] investigate the supply water quality in the Chittagong City of Bangladesh. In this study, though the measured value of $\mathrm{pH}$, turbidity, alkalinity, hardness was largely within the acceptable range, $\mathrm{BOD}_{5}$ value of almost all the selected samples was considerably higher and faecal coliform as well as total coliform was also found at some locations of the distribution system. In 2013, Fahmida et al. [10] studied on the supplied water quality (parameters include $\mathrm{pH}$, color, turbidity, iron, chloride, arsenic, hardness, $\mathrm{BOD}_{5}$, total solid, total suspended solid, total dissolved solid, total coli form and Escherichia coli) of Khulna WASA of Bangladesh and found that the water inflowing the distribution system was not meet the desired chemical and microbial quality except $\mathrm{pH}$, turbidity, chloride and iron.

There are significant chances of pollution in supply systems from sources to households. There may be leakage in the pipes for construction works, pressure, etc. which may create pollution of water in the system. The supply mains should be clean, free from cracks, and close monitoring of the water at number of points have to be implemented.

\section{List of Symbols and Abbreviations}

$\begin{array}{ll}\text { BD } & \text { Bangladesh Standard } \\ \text { FC } & \text { fecal coliform } \\ \text { ISI } & \text { Indian Standard Institute } \\ \text { SCC } & \text { Sylhet City Corporation } \\ \text { SDDC } & \text { silver diethyldithiocarbamate } \\ \text { SWTP } & \text { surface water treatment plant } \\ \text { TC } & \text { total coliform } \\ \text { TDS } & \text { total dissolved solids } \\ \text { TH } & \text { total hardness } \\ \text { WHO } & \text { World Health Organization } \\ \text { DTW } & \text { groundwater with deep tube well }\end{array}$

\section{References}

[1] M. Hoque, S. Ahmed, M. J. Alam, M. Purkayastha, A. Belal, and M. A. Anwar (2012). Physicochemical and microbial water quality of Sylhet city corporation, Bangladesh. International Journal of Natural Sciences 2(1), pp. 33-37.

[2] M. F. R. Zuthi, M. Biswas, and M. N. Bahar (2009). Assessment of supply water quality in the Chittagong City of Bangladesh. ARPN J. Eng. Appl. Sci. 4(3), pp. 73-80.

[3] A. Rahman, M. A. Zafor, and M. Rahman (2012). Surface water quality and risk assessment in the vicinity of Sylhet City. International Journal of Water Resources and Environmental Engineering 51, pp. 29-34.

[4] ASTM Standard D 5907, (2004). Standard test method for filterable and nonfilterable matter in water. ASTM International, West Conshohocken, PA, United State.

[5] WHO-World Health Organization, (2006). Guidelines for drinking water quality. First addendum. Vol. 1, Recommendations. 3rd edn.

[6] ECR- The Environment Conservation Rules, (1997). Government of the People's Republic of Bangladesh Ministry of Environment and Forest, S.R.O. No. 197-Law/97.

[7] IS 10500, (2012). Drinking Water- Specification (Second Revision). Bureau of Indian Standards, ManakBhavan, 9 Bahadur Shah Zafar Marg, New Delhi 110002. 
[8] R. Alam, J. B. Alam, M. M. Hasan, S. R. Das, K. Rahman, andB. K. Banik (2005). Study of water quality of Sylhet city and its restaurants: health associated risk assessment. Iran. J. Environ. Health Sci. Eng. 3(1), pp. 9-18.

[9] G. M. Munna, M. M. I. Chowdhury, A. A. M. Ahmed, S. Chowdhury, and M. M. Alom (2013). A Canadian Water Quality Guideline- Water Quality Index (CCME-WQI) based assessment study of water quality in Surma River. Journal of
Civil Engineering and Construction Technology 4(3), pp. 81-89.

[10] K. Fahmida, Md. H. R. Lemon, M. S. Islam, M. A. Kader (2013). Assessment of Supplied Water Quality of Khulna WASA of Bangladesh. International Conference on Mechanical, Industrial and Materials Engineering 2013 (ICMIME2013), 1-3 November, 2013, RUET, Rajshahi, Bangladesh, pp. 852-857. 